\title{
The Involvement Of Austin's Ideas In Semantics
}

\author{
Dimjati Ahmadin
}

Penulis adalah Pembantu Dekan I Fakultas Sastra dan Humaniora UIN Malang, Kandidat Doktor pada Universitas Negeri Malang.

\begin{abstract}
Abstrak
Terdapat petunjuk dari teori tindak tutur bahwa pada periode awal, terdapat perbedaan pendapat di antara para ahli filsafat, sama seperti perbedaan antara Ibnu Sina dan Thomas Hobbes, pertama kali untuk meneliti masalah tersebut dengan tegas dan lengkap yaitu penelitian yang dilakukan oleh J.L. Austin (ahli filsafat bahasa) dengan judul "Masalah Ujaran Performatif". Austin mengemukakan pendapatnya bahwa mengatakan sesuatu berarti melakukan sesuatu. Sebagaimana diketahui bahwa semantik adalah merupakan cabang ilmu kebahasaan yang utama yang mempelajari tentang arti dalam bahasa, diperkirakan bahwa di antara mereka yang membicarakan tentang semantik tentu akan melibatkan ide-ide Austin dalam pembahasan mereka. Namun selaras dengan perkembangan ilmu-ilmu sosial, dan diketahui bahwa teori ilmu-ilmu sosial hampir tidak pernah konstan termasuk semantik, dan penulis juga percaya bahwa mereka yang melibatkan ide-ide Austin dalam pembahasan mereka, mungkin memiliki ide-ide yang berbeda dengan Austin. Hal ini penting untuk menentukan makna suatu ujaran dalam komunikasi. Penelitian kepustakaan ini bermaksud untuk mempelajari apakah dua orang penulis terkemuka dalam bidang semantik yaitu John Lyons dalam bukunya "Linguistic Semantics" dan Ruth Kempson dalam bukumya "Semantic Theory" melibatkan ide-ide Austin dalam pembahasan mereka. Berdasarkan data yang diperoleh serta diskusi yang telah dilaksanakan dapat
\end{abstract}

Ulul Albab, Vol. 5 No. 1, 2004 
diambil kesimpulan bahwa kedua pakar semantik tersebut melibatkan ide-ide Austin di dalam pembahasan mereka dalam semantik. Namun, cara mereka melibatkan ideide Austin dalam pembahasan mereka bervariasi antara yang satu dengan yang lain, hal ini selaras dengan perkembangan ilmu-ilmu sosial yang tidak pernah konstan termasuk semantik, sebagimana disebutkan dalam pembahasaan sebelumnya. Selanjutnya juga dapat disimpulkan bahwa kedua pakar semantik tersebut mengambil keuntungan dari ide-ide Austin di dalam pembahasan mereka walaupun kadangkadang pendapat mereka berbeda dengan Austin.

\section{Background of the Study}

Semantics is a crucial subject at least if it is seen from two aspects, they are language teaching and communication. Related to language teaching Wahab states that students, teachers and experts are conscious that semantics is one of the important elements of the study of language as its two siblings-phonology and syntax. Logically, semantics must not be neglected in the study of language. In spite of its significant status in linguistic study, in addition to the two others, negligence of semantics may cause inappropriateness in teaching lexical and sentential meanings. On the level of lexical meaning, ignorance of semantics in

TEFL may create false concept of synonymy antonymy, and ambiguity. On the level sentential meaning, problems of grammaticality and acceptability may appear.

Due to the function of language, namely, as a means of communication, we also naturally learn language for our daily life communication. Learning a.language includes learning the 'agreed-upon' meanings of a certain strings of sounds and learning how to combine these meaningful units into larger units that also convey meaning. It shows that the study of meaning or practical semantics is also needed for those who want to be a good speaker or writer or communicate better in their daily life activities. Deals with this case, Leech $^{2}$ states that semantics (as the study of meaning) is central to the study of communication; and as communication becomes more and more a crucial factor in social organization; the need to understand it becomes more pressing. 
The problem of this study is to know whether two prominent writers in semantics, namely, John Lyons in his book entitled "Linguistic Semantics" as well as Ruth Kempson in his book entitled "Semantic Theory" involve Austin's ideas or not in their dscussion about semantics. Objective of the Study. In acordance with the rsearch problem stated previously the objective of this study is to present the description about the involvement of Austin's ideas in semantic discussion. Significance of the study. The results of this study is significant to determine the meaning of a certain uterance in any communication conducted by people who apply language as a means of communication

Furthermore, the description above shows that semantics as a branch of linguistics devoted to the study of meaning is quite crucial not only for language teachers and students but also for those who want to communicate better in the society. Since the study of meaning or practical semantics especially deals with sentence, utterance or discourse meaning normally deal with philosophy, the discussion in semantics sometimes cannot avoid involving a philosopher's ideas. it may improve our keen understanding of practical semantics if we know or understand the involvement of a philosopher's ideas in a certain semantic discussion.

\section{Theoretical Framework}

The theory underpinning this study is speech act semantics; the central insight of $i$ is that we use language to do things, that describing is merely one of the things we do: we also apply language to agree, criticise, insult, warn, promise, etc. Austin advise that a speaker is usually involved in three different acts in uttering a sentence. They are locutionary act, illocutionary act a perlocutionary act. Locutionary act is the act of uttering a sentence with certain meaning, illocutionary act is the act uttering a sentence to constitute an act of criticism, warning, promise, agreement, praise, insult etc, while perlocutionary act is the act of uttering a sentence to attain a certain consequent response from one's hearer. 


\section{Methodology}

This study is textual analysis design since it is aimed at investigating the involvement of Austin's ideas in semantic discussion done by John Lyons in his book entitled "Linguistic Semantics" and the involvement of Austin's ideas in semantic discussion done by Ruth Kempson in his book entitled "Semantic Theory" as well. Related to text analysis, Denzin (1994:394) states that equally different type of text have to be understood in the contexts of their conditions of production and reading.

Following Bogdan and Biklen (1998), this study is also considered qualitative one due to the followng reasons. First, it intends to investigate the involvement of Austin's ideas in semantic discussion done by two prominent semantic writers as it was stated in the preceding discussion. Second, it requires the researcher as the key instrument since such study of the involvement of a philosopher's ideas in a certain text of semantic discussion demands particular knowledge of semantics and language philosophy. Third, this study focuses on description and explanation of the phenomenon being studied.

The idea in considering the reseracher as the key instrument is based on the following reasons. Human beinng is responsive, and he or she can sense and response to all personal and environmental clues; therefore, he or she can communicate with situation to sense its dimension and make them explicit. He or she has adaptability and can collect multiple factors and multiple levels of information simultaneously. He or she has holistic emphasis, and he or she is the only one availabl and capable of grasping and understanding the overall phenomena of the world and its surrounding context better. He or she has knowledge base expansion, and he or she is competent to function simultaneously on the nasis of proportional and tacit knowledge. He or she has processual immediacy and can make the gathering of the appropriate data possible and can directly sort which of the available data are to be included and which are not. He or she has opportunities for clarification and summarization. It is possible for human instrument to process data after data collection, and the data colecting includes summarizing data, clarifying the summarized data, correctng and amplifying them in the spot. He or she has opportunity to explore typical or idiosyncratic responses, he or she can give conceptual response to the collected 
data, and he or she has the ability not only to test the validity of the data but also to achieve a higher level of understanding the data collected (Lincoln and Guba, 1985:107).

Data Analysis. The data of this study are analyzed in the following steps. First of all, the data are categorized into two categories which are in accordance with the number of semantic writers whose works are investigated. The data of each category are presented, analyzed and concluded. After the data of the whole categories have already been analyzed, discussed and concluded. the writer makes tentative conclusion. Furthermore, after consulting with the informants the writer makes final conclusion.

\section{Results and Discussion}

Data presentation, discussion and conclusion of the data from the first category.

The first discussion put forward here is Lyons. Lyons ${ }^{3}$ states that one of the most influential critics in recent years was the Oxford philosopher.J.L. Austin ${ }^{4}$ . whose ideas have been discussed frequently, not only by philosophers. but also by linguists, and many other discipline as well. In this part. Austin's theory of socalled speech act as a departure-point for the analysis of utterance-meaning. The term 'utterance', as was point out previously is ambiguous as between a process sense and a product sense (1.6). ('Process' is here being used as a term which is broader than 'action' or activity.) The term utterance can be used to refer either to the process (or activity) of uttering or to the product of that process (or activity). Utterances in the first of the two senses are commonly referred to nowdays as speech acts; utterances in the second sense may be referred to- in a specialized sense of the term - as inscriptions. (The term inscription, which was produced in the preceding discussion, is not widely used by linguists. It must not be interpreted as being more appropriate to the written than it is to the spoken language). It is one of my fundamental goals in this part to clarify the relation between speech acts and inscriptions and, in doing so, to develop in more detail the distinction between sentence meaning and utterance meaning. I will operate, as far as possible, with the terms and concepts which derived from the work of J.L. Austin and are now widely applied in linguistics and related discipline. Yet, I 
shall need to add one or two distinctions of my own, in order to make more precise than Austin and his followers have done the rather complex relation that holds between speech acts and sentences. I will also introduce into the discussion points which are given less focus in what may be referred to as the AngloAmerican tradition than they are in the typically French tradition which looks from the work of Emile Benveniste ${ }^{5}$ (1

The term 'speech act' is somewhat misleading. First of all. it might seem to be synonymous with "act of utterance". rather than to show - as it does (in the sense in which it does (in the sense in which it tends to be applied by linguists) - some particular part of the production of utterances. Second. it throws too much emphasis on that par of the production of utterances which results in their inscription in the phy sical medium of sound. Nevertheless. because "speech act" is now widely applied. in linguistics and philosophy. in technical sense that Austin and more particularly J.R. Searle ${ }^{f}$ gave to it I will make no attempt to replace it with another more appropriate term. It must be focused. nevertheless. that (i) 'speech act' is being applied throughout in a highly specialized sense and (ii) like "utterance". on the other hand. and "inscription" or "text". on the other, is intended to cover the production of both written and spoken language. Everything that is said in this part is intended to be consistent with what was said previously about competence and performance. on the one hand. and about the language system and the use of language system. and the products of the use of language system. on the other. and to be neutral with respect to a number of differences which divide one school of linguistics from another at the present time.

As we have seen. when Austin first concerned himself with the question. the verificationists had already had to face the objection that their criterion of meaningfulness had the effect of ruling out. not only the so-called pseudostatements of theology and metaphysics. but also those of ethics and aesthetics. One response to this objection. it will be recalled, was to concede that such sentence such as:

'Cannibalism is wrong'

'Monet is a better painter than Manet'

The utterances above cannot be used to make descriptive statement. but only emotively: i.e. . to express one's feelings. 
Another was to say that, although such sentences can be used to make true or false statements, what speakers are describing when they make such statements are their own or someone else's attitudes. rather than objective reality. What Austin did in his relatively early papers was to criticize the second of these alternative. He subsequently pointed out that many more of our every day utterances are pseudo-statements than either the verificationists or their opponents had realized. For example. according to Austin, if one utters the sentence:

'I promise to pay' you Rp 30000 .' with the purpose of making a promise (and of communicating to one's addressee the fact that one is making a promise). one is not saying something. true or false, about one's state of mind. but committing oneself to a particular course of action.

This. in brief. is the philosophical context in which Austin first put forward his now famous distinction between constative and performative utterances. A constative utterance is by definition. a statement-making utterence. Austin would rather "constative' to 'descriptive'. since. in his idea. not all true or false tatement are description. For simplicity of exposition in the present context. the two terms may be considered as similar.). Performative utterances in contrast. are those in the production of which the speaker. or writer. performs an act of doing rather than saying.

Of course. one can make a promise without doing so by uttering an explicit performative. For instance one can make a promise by uttering the sentence:

"I will pay you Rp25000,

In this case one will have produced what Austin refers to as a primary (i.e.. non explicit) performative based on the definition given above. in that there is no expression in the utterance inscription itself ( I'll pay' you Rp25000) which makes explicit the fact that it is to be taken as a promise rather than a prediction or a statement.

\section{Locutionary Acts}

To perform what Austin called a locutionary act is 10 produce an utterance (i.e.. an utterance inscription) with a particular form and a more or less determinate meaning. Most of our locutionary acts are grammatical but ellipticall. ungrammatical, neither grammatical nor ungrammatical, both ungrammatical and 
unacceptable-resulting from so-called performance errors, inattention, , lapses of memory or malfunctioning of one kind or another in the actual production of language signals.

Let us begin by noting that the following sentence is ambiguous, according to whether the verb "say' is taken as meaning "assert" or "utter" as:

'John and Mary said the same thing'

Under one interpretation, it has much the same. truth condition and therefore the same prepositional content, as:

'John and Mary asserted the same proposition'

Under the other, it may be paraphrased. in the technical metalanguage that we have been building up, as:

John and Mary produced the same utterance-inscription

Illocutionary Force

Saying is doing. But there are distinguishable senses of he verb 'say" . In one sense, it means roughly "utter" or, more technically, "perform a locutionary act" . As we have just seen. saying in this sense of the verb involve three different kinds of doing . the are: the act of producing an inscription; the act of composing a sentence, and the act of contextualizing that sentence.

To utter a sentence. in all normal communicative contexts, is to perform a complex act in which these three kinds of doing are integrated and have as their product identifiable and meaningful language signal : utterance-inscription.

They can say that something is. or is not, the case : that is, they can assert the same proposition. For example. let us suppose that John says (or writes):

Peter is mad.

and Mary, on some other occasion, says (or writes)

Your brother is mad.

Let us further suppose that 'Peter" and 'your brother' refer to the same sense (rather than on one occasion with the meaning "insane" and on the other with the meaning "angry"). Provided that they have indeed asserted a proposition, John and Mary will have asserted the same proposition, and will therefore have said the same thing in this other sense of 'say'. 
Looked at from this point of view, sentences such as:

'I promise to pay you Rp100 000,-

were obviously greater theoretical interest that sentences such as:

'I will pay you $\mathrm{Rp} 100$ 000,-

In terms of the later, more general, notion of illocutionary force which he develop in How to do Things With Words, we have no grounds for confining our attention to declarative sentences containing performative verbs. ${ }^{7}$

The data presented above show that Lyons involved Austin's ideas to explain about "utterance meaning". At the beginning of his discussion he stated that the term "speech act' is somewhat misleading; however, he used the term from the beginning until the end of his discussion in describing about utterance meaning because according to him it is widely applied by both linguists and other fields. In addition, he involved pseudostatement, that is neither true nor false in describing about ethic and aesthetic words as Austin did. Then he involved performative utterances as the opposite of constative ones. Next he involved locutionary acts that is to produce an utterance-with a particular form and a more or less determinate meaning. He confirmed that the utterances we produce in every conversation i.e most of the product of our locutionary acts - are ungrammatical; some are grammatical ; but elliptical (e.g. Been here long? Nice weather for the time of year, etc) some are neither grammatical nor ungrammatical; yet others, of course, are both ungrammatical and unacceptable - resulting from so called performance errors: inattention, lapses of memory or malfunctioning of one kind or another in the actual production of language- signals. He did divide locutionary acts into sub groups, namely, phonetic acts, phatic acts and rhetic acts as Austin did. Then, he reinvolved performative utterances in the discussion of illocutionary acts as he did at the beginning his discussion about utterance meaning. However he did not involve anything about perlocutionary act in the discussion about utterance meaning.

Data presentation, discussion and conclusion of the data from the second category 
The second discussion put forward here is Kempson's . Kempson ${ }^{8}$ states the central inside of speech act semantics is that we use language to do things, that describing is only one of the things we do: we also use language to promise, to insult, to agree, to criticize, etc. Austin himself suggested that in uttering a sentence, a speaker is generally involved in three different acts (Austin 1962: lecture VIII) . First there is the locutionary act: the act of uttering a sentence with a certain meaning. In addition the speaker may have intended his utterance to constitute an act of praise, criticism, agreement, etc. : this is the so-called illocutionary act. Finally he may have uttered the sentence he did utter to achieve a certain consequent response from his hearer - for example to frighten him, to amuse him, to get him to do something: this is the perlocutionary act. Suppose it really occurs that my child is refusing to lie down and go to sleep, then I say to him, "I"ll turn your light off" Now the locutionary act is the utterance of the sentence "I'll turn your light off".

In some cases the illocutionary force is made plain. These are the socalled explicitly performative utterances:

-I promise you that I'll come.

-I bet you she'll fall over.

-I agree that I was wrong.

It was this type of utterances of which Austin said it made no sense to talk of its being true or false because such utterances are not descriptions but actions. Austin ${ }^{9}$

These are different from other utterances using the same verbs as follows:

-He promised her that he would be here.

-She bet you that would fall over.

-They agree that I was wrong.

None of the last three sentences can be used as performative utterances for they would all be used as descriptions, not as actions, of promising, betting or agreeing.

Austin suggested that performative utterances, instead of being assessed as correct or wrong, could only be assessed as appropriate or not, and they could be characterized accordingly in terms of differing sets of conditions necessary 
for their appropriate use. For example, among the appropriacy conditions of an utterance of I promise you that $I$ will be at the station are that the speaker intends that his utterance will place him under an obligation to be at the station, that he intends to be at the station, that the hearer would prefer his being at the station, and that it is not obvious that he would otherwise be at the station in the normal way of things. In addition, there are standard conditions for successful communication, such as that both speaker and hearer, speak the same language or understand from each other, that if they are in a speech situation the hearer is not stone deaf. All these conditions must be fulfilled if the utterance is to count as a successful and suitable promise. Now just as we saw that all utterances and not only performative utterances could be seen as simultaneously comprising three different acts, locutionary, illocutionary, and perlocutionary, so the concept

It is no coincidence that up to the present time Kempson has referred to utterances in talking of illocutionary acts. The analysis of speech acts given by Austin, and extended by other philosophers after him, is an account of acts of speech, of utterances: it was not aimed at an account of sentences. Nevertheless, recently linguists have turned to the account of speech acts as solution to the problem of meaning. It has been suggested that rather than talk of words meanings or sentence meanings in vacuo, one can more beneficially talk about situations for appropriate use for both sentences and words, Filmore ${ }^{10}$

In addition, a semantic theory which explains meaning in term of use is assuming that an explanation of use is logically prior to an explanation of meaning : appropriate use is the primitive notion, in term of which the concept of meaning is to be explained. Thus if we keep the Saussurean langue - parole dichotomy ${ }^{1 i}$ under the name of competence and performance as outlined in Chomsky ${ }^{12}$, we have arrived at an impasse - we are describing performance in terms of competence grammar which generates sentences in their meanings; however, we are explaining those meanings in term of conditions for their use, namely, their performance. If we maintain a speech act view of semantics, next we must at the very least reconsider the assumptions made in the competence-performance distinction.

The problem in assessing a speech act semantics as the basis of an account of the interpretation of the elements of language, sentences and words, lies in the extension of the term speech act, illocutionary force, and appropriacy condition 
from the utterance to the sentence. As we shall see at once, this extension raises serious problems. Recall that the concept of appropriacy conditions was first introduced in Austin's analysis of those utterances which were explicitly linguistic actions, namely, performative utterances. He proposed that all utterances were actions in this sense whether the type of act performed was made explicit with performative verb or not. The concept of appropriacy conditions must therefore in any case be generalisable to all utterances. The problem which we face in the prediction of ambiguity is that those sentences that do not have any explicit illocutionary force indicator can be used in a variety of ways. For instance the sentence There are four large bulls in that field may be used as a warning ( to a walker who is about to cross the fence), a statement (to a new assistant on the farm) a boast (to fellow farmer), or a thread (to a boy who is misbehaving), to name but a few possible linguistic actions for which this sentence could be used. Nevertheless, conditions for appropriate use are defined on utterances, not or not merely on the sentence being used, for they depend on what act is being carried out. Therefore, the conditions for the appropriate use of the above sentence as a warning will differ from those for its appropriate for any other action: the appropriacy conditions for warning, stating, boasting and threatening, for examples, are all distinct.

The data presented above show that Kempson applied Austin's ideas to present the description about "Speech act Semantics". If Lyons in his description about utterance meaning only involve locutionary and illocutionary act (in the preceding discussion), Kempson in his discussion about Speech act semantics involve locutionary, illocutionary and perlocutionary act. Kempson did not divide locutionary acts into three subgroups, namely, phonic act, phatic act, and rhetic act whereas Austin and Lyons did divide locutionary acts into three subgroups, namely, phonic act, phatic act and rhetic act. .Lyons in his description about utterance meaning involved two kinds of pseudostatements, namely, ethic and aesthetic while Kempson in his discussion about speech act semantics didn't.

Contribution to semantics has come essentially from two sources, namely, linguistics and philosophy. Linguists have contributed primarily to the study of the core meaning or sense of individual words(lexical meaning), Manis ${ }^{13}$, on the contrary philosophers have contributed primarily to the study of both sentence or utterance meaning and discourse meaning. Therefore, Kempson' statement about 
serious problems of ambiguity which are caused by the extension of the terms speech act, illocutionary force and appropriacy condition from the utterance to sentence may be avoided if both the speaker and the hearer understand the role of context in interpretation of either utterance or discourse for instance in implicature (Grices' idea):

A: I am out of petrol. B. There is a garage round the comer. Brown ${ }^{14}$

$B$ would be infringing the instruction via the literal meaning of his utterance.

The grammatical form of a declarative sentence (It's cold in here.) might well be used, in the appropriate circumstances, uncharacteristically and indirectly, instead of (Close the window please!) $)^{15}$ On the other hand, presupposition originated in the philosophy of logic is used to denote a special type of implicit information ${ }^{16}$ Renkema and Gazdar .

The preceding discussion shows that all utterances were actions in this sense whether the type of act performed was made explicit with a performative verb or not, and it depends on the context in which an utterance or sentence is used.

The conclusion of the whole calegories above are sumarized in the form of final conclusion which are considered as the finding of the study that is written in the last part of the this research repon(Chapter V).

\section{Conclusion}

Based on the data presentation and discussion above the following conclusion is drawn.

A. Both John Lyons in his book entitled "Linguistic Semantics" and Ruth M. Kempson is his book entitled "Semantic Theory" involved Austin's ideas.

B. The way they involved Austin ideas vary from each other.

C. Although both Lyons and Kempson criticized Austin's ideas, it seems that both experts get advantages from Austin's ideas.

D. All utterances are actions whether the type of act performed was made explicit with a performative verb or not. 


\section{Endnotes}

1 Abdul Wahab. Semantics: A Neglected 'Fellow' in Teaching English as a Foreign Language. In Sadtono, E. (eds). The Development of TEFL in Indonesia. (Malang: Penerbit IKIP Malang, 1997)

2 Geofrey Leech, Semantics (New York: Penguin Books, 1977)

3 John Lyons, Linguistic Semantics ( Cambridge: Cambridge University Press, 1995)

4 John L. Austin, How To Do Things With Words (Oxford: Clarendom Press, 1962)

5 Emile Benveniste, Problemes de Linguistique Generale ( Paris Gallimard. 1974)

6. John Searle; D. Vanderken. Foundation of Illocutionary Logic (Cambridge: Cambridge University Press, 1985)

7 David Cooper, Philosophy and the Nature of Language (London: Longman Group Limited, 1973)

* Ruth M. Kempson. Semantic Theory (Cambridge: Cambridge University Press. 1977)

9 John L. Austin, 1962, Op. Cit.

10 C.J. Fillmore, and Langendoen, Studies in Linguistic Semantics (Holt, Rinehart Winston, 1971)

11 Lavandera R. Beatriz. The Study of Language in Its Socio-cultural Context (Cambridge: Cambridge University Press, 1988)

12 Chomsky, Aspect of the Theon of Syntax (Cambridge: MIT Press, 1965)

13 Mc Manis, Carolyn. Language File (Ohio: Advocate Publishing Gropup)

14 Gillian Brown et. al. Discourse Analysis (Cambridge: Cambridge University Press, 1996)

35. John Lyons, Language and Linguistics (Cambridge: Cambridge University Press, 1984)

16 Jan Renkema. Discourse Study (Amsterdam: John Benjamin Publishing Co, 1992) Gerald Gazdar, Pragmatics (New York: Academic Press, 1979)

\section{References}

Austin, John L. 1962. How To Do Things With Words. Oxford: Clarendon Press. Benveniste, Emile. 1974. Problemes de Linguistique Generale. Paris: Gallimard. Bogdan, Robert C; Sari Knop Biklen. 1998. Qualitative Research for Education. Boston: Allyn and Bacon. 
Brown, Gillian; Yule George. 1996. Discourse Analysis. Cambridge: Cambridge University Press.

Chomsky, Noam. . 1965. Aspect of the Theory of Syntax. Cambridge, MA: MIT Press.

Cooper, David E. 1973. Philosophy and the Nature of Language. London: Longman Group Limited.

Denzin, Norman K; Lincoln, Ivonna S. 1994. Handbook of Qualitative Research. London: Sage Publication Ltd.

Filmore, C.J. and Langendoin. 1971. Studies in Linguistic Semantics. Holt Rinehart Winston.

Fromkin, Victoria; Rodman, Robert; Collin, Peter, Blair, David. 1988. An Introduction to Language. Sydney: Holt, Rinehart and Winston.

Gazdar, Gerald.1979. Pragmatics. London: Academic Press Inc.

Kempson, Ruth M. 1977. Semantic Theory, Cambridge: Cambridge University Press.

Lavandera Beatriz R. 1988. The Study of Language in It's Socio-cultural Context. Cambridge: Cambridge University Press.

Leech, Geofrey. 1977. Semantics. New York: Penguin Books.

Lincoln. Y.S. and E.G. Guba. 1985. Naturalistic Inquiry. Beverly Hills: Sage Publication

Lyons, John. 1984. Language and Linguistics. Cambridge: Cambridge University Press.

Lyons, Johns. 1995. Lingyuistic Semantics. Cambridge: Cambridge University Press.

Mc Manis, Carolyn. 1987. Language Files. Ohio: Adfvocate Publishing Group.

Martinich, A.P. 2001. The Philosophy of Language. Oxford: Oxford University Press.

Pustejovsky, James. 1993. Semantics and the Lexicon. Dordrecht: Kluwer Academic Publisher.

Searle, John; Vanderken.D. 1985. Foundation of Illoqutionary Logic. Cambridge: Cambridge University Press. 